\title{
Comparative Analysis of Derivational Prefixes of Dari Persian and Their Russian Equivalent
}

\author{
Ahmadi Zahra ${ }^{1}$ \\ $\mathrm{PhD}$, Tajik National University, \\ Dushanbe, Tajikistan. \\ Mohammad Beygi Kasvaei Mahdi \\ $\mathrm{PhD}$, Tajik National University, \\ Dushanbe, Tajikistan. \\ Haitova Shirin ${ }^{3}$ \\ Associate Professor, Tajik National University, \\ Dushanbe, Tajikistan.
}

(date of receiving: January, 2019; date of acceptance: May, 2019)

\begin{abstract}
In this article, using of the example of lexical material of the well-known literary monument "Zakhire Kharazmshahi" Seyyed Ismail Jorjani is tasked to conduct a comparative analysis of word-form consoles in Dari Persian language and their Russian equivalents. Authors of the article consider various approaches to study the prefix word formation method in the two languages under consideration. The subject especially was studied from the point of view of semantic-syntactic specifics in two languages about prefixes, which were subjected to partial consideration. When selecting the values of authors, problem of lexica-semantic features of the prefix verbs is touched upon. In the process of studying, the most common prefixes and their Russian equivalents were identified and analyzed, their semantic similarities were revealed. It is noted that some prefixes during historical development of Persian language underwent phonetic changes. Some prefixes, which previously acted as independent words, eventually turned into a derivational morpheme.
\end{abstract}

Keywords: Morpheme, Affix, Prefix, Meaning, Productive, Dari Persian, Russian Language.

\footnotetext{
${ }^{1}$ E-mail: ahmadikazahra@yahoo.com

2. Email: mahdimb@yahoo.com

3. E-mail: haitova@inbox.ru
} 


\title{
Сравнительный анализ словообразовательных префиксов персидского дари и их русские эквиваленты
}

\author{
Ахмади Захра ${ }^{1}$ \\ Канд. филологических наук, Таджикский национальный университет, \\ Душанбе, Таджикистан. \\ Мухаммадбегии Косвои Махдии \\ Канд. филологических наук, Таджикский национальный университет, \\ Душанбе, Таджикистан.
}

Хаитова Ширин

Доцент, Таджикский национальный университет, Душанбе, Таджикистан.

(дата получения: январ 2019 г.; дата принятия: май 2019 г.)

\begin{abstract}
Аннотация
В данной статье на примере лексического материала известного памятника письменности «Захираи Хорезмшахи» («Сокровищница Хорезмшаха») Сейид Исмаила Джурджани поставлена задача провести сравнительный анализ словообразовательных приставок языка персидского дари и их русских эквивалентов. Авторами статьи рассмотрены различные подходы изучения префиксального способа словообразования в двух анализируемых языках. Предметом специального исследования с точки зрения семантико-синтаксической специфики в двух языках явились префиксы, которые были подвергнуты частичному рассмотрению. При выделении значений авторами затрагивается проблема лексико-семантических особенностей приставочных глаголов. В процессе изучения были выявлены и проанализированы наиболее употребительные префиксы и их русские эквиваленты, выявлены их семантические сходства. Отмечается, что некоторые префиксы в ходе исторического развития персидского дари претерпели фонетические изменения. Некоторые префиксы, выступавшие ранее в качестве самостоятельных слов, со временем превратились в словообразовательную морфему.
\end{abstract}

Ключевые слова: Морфема, Аффикс, Префикс, Значение, Продуктивный, Персидский Дари, Русский Язык.

\footnotetext{
${ }^{1}$ E-mail: ahmadikazahra@yahoo.com

${ }^{2}$ Email: mahdimb@yahoo.com

${ }^{3}$ E-mail: haitova@inbox.ru
} 


\section{Введение}

В культуре каждого народа существуют доминанты, которые закреплены в языке. Для каждого народа существует наборр ценностей, который повторяется и в других культурах. В настоящее время одним из основных направлений в типологической лингвистике является сопоставительное изучение разноструктурных языков. Как известно, очень часто одним из компонентов сопоставительного анализа часто выступает русский язык.

Еще Щерба указывал на то, что «контрастивные исследования помогают проникнуть в суть языковых процессов и глубже понять законы, управляющие этими процессами, поэтому контрастивная лингвистика является той областью исследования, где пересекаются пути теории и практики» (Щерба 1974. 79-121). В ходе работы авторами был использован синхронно-описательный и сопоставительный методы исследования.

На протяжении всей истории персидский язык, в том числе и персидский дари, широко пользовался словообразовательными аффиксами, так как его формирование, сохранение и развитие зависело во многом от наличия аффиксов, так как аффиксы играют важную роль в развитии семантических возможностей и обогащении словарного запаса языка.

Ходжа Хасани Нисори так формулирует аффиксы: «Аффикс - это морфема, которая в отдельности не употребляется и не имеет смыслового значения, то есть, она не употребляяется без существительного, либо без глагола...» (Нисари. 1930. 4).

Другой иранский лингвист Ханлари указывает, что аффиксы используются в составе других слов, чтобы придать им новые значения (Нательханлари 1975. 164).

\section{Основная часть}

Важную роль в формировании, сохранении и развитии языка, а также в развитии его семантических возможностей играют словообразовательные 
аффиксы. Как утверждает иранский лингвист Мишкотуддини, производные морфемы имеют две особенности: а) грамматические категории, образованные путем словообразовательных способов, отличаются от первоначальных лексических единиц; б) ключевые термины одной категории не употребляется со всеми аффиксами (Мешкатуддини 2009. 16).

Префиксация, как процесс образования новых слов при помощи приставок, являются нанболее продуктивным способом расширения состава глагольной лексики как в персидском дари, так и в русском языке. Под приставкой понимают одну из морфем, $\mathrm{c}$ помощью которой выражается словообразовательное или грамматическое значение слова.

Проблема сопоставительного изучения особенностей приставок имеет большое значение, прежде всего, потому, что оно важно для определения механизма взаимодействия и взаимосвязи словообразовательного и семантического уровней сопоставляемых языков - персидского дари и русского. Как отмечает О.В. Почтарева, «интерес к вопросам префиксации не ослабел и в наши дни, так как глагольное приставочное словообразование связано с обширным кругом общих и частных вопросов лингвистики) (Почтарева О.В. 2001).

В современных работах, посвященных виду и особенно способам глагольного действия, как правило, часто затрагивается семантика приставок, а иногда её описание занимает важное место, о чем свидетельствуют работы, посвященные изучению префиксации: «Русские глагольные приставки: семантическое устройство, системные отношения» (Г.А. Волохина и 3.Д. Попова 1994), «Семантический аспект русской глагольной префиксации» (Л.А. Вараксин 1996), «Приставки и глаголы в современном русском языке: Семантическая грамматика» (М.А. Кронгауз 1998); «Глагольная префиксация в русском языке» (сборник научных статей 1997) и др.

В 2001 г. под редакцией Е.Р. Добрушиной и Д. Пайара был выпущен сборник «Русские приставки: многозначность и семантическое единство», 
давший описание семантики приставочных глаголов и приставок русского языка. Большую роль при выборе той или иной приставки играют семантика и грамматические свойства бесприставочного глагола. Как указывает В.В. Морковкин, «присоединение любой приставки производящим глаголом влечет за собой изменение в их семантике» (Морковкин 1981. 45).

Как известно, каждой глагольной приставке присуще своё значение. Появление новой лексемы свидетельствуют о том, что именно приставки фактически становятся носителем семантики новых лексических единиц. Префиксальные глаголы и их словообразовательные типы характеризуются разнообразием, они отражают состояние словообразовательной системы языка. Особенности их употребления обусловлены различными значениями, которые они выражают: временными, пространственными, количественными.

Как отмечает Падучева Е.В., в русском языке «приставка меняет смысл глагола, создавая обязательную «направительную» валентность. Можно сказать, что приставка вносит определенность акцента - фиксирует акцент на одном из ориентиров, чего не было у исходного глагола» (Падучева 2002. 129).

В ходе анализа лексического материала «Захираи Хоразмшохи» было выявлено 12 префиксов: /ā-/, /andar-/, /bā- (ba-)/, /bāz/,/bar-/, /foru-/, /do J -/, /be(bi-)/, /na-, ne-/, /nā-, /(be-), ba-, (bi-)/, /par/.

Русская грамматика дает следуюшие глагольные приставки: по-, с-, за-, о-, на-, про-, вы-, у-, в3-, от-, раз-, из, при-, воз-, пере-, под- (Спагис 1968. 40).

У глагольных приставок, как известно, вначале были лишь локальные (пространственные) значения, например, в современном русском языке, локальное значение приставки в- - «внутрь» (вселиться, вбросить), из- «наружу» (излучать, изгнать). Постепенно у префиксов появились и другие значения, например, пространственное значение префикса из- было переосмыслено до значения уничтожиться (исписать). В ходе исторического развития как в персидском дари, как и в современном русском у большинства приставок появилось по нескольку значений. 
В персидском дари начальная $\bar{a}-/ \mathbf{a}-/$ некоторых глаголов, являющаяся в настоящее время частью корня, ранее употреблялась в качестве приставки, например, /āsudan/ (отдохнуть), /āmadan/(приходить), /āvardan/ (приносить).

В русском языке существуют исконно русские слова, образованные при помощи непродуктивных архаичных приставок: су- (суароб, сумрак, супесь, супруги, сусек, сумерки, суржик, сукровича, суглинок, сумятица, сутолока); ка-/ко- (каверза, колдобина, колупать, корьтто, ковылять, ковырять); ку(кудель, кудри, скукожить, кумекать, кувырок); па- (паводок, пагуба, падчерица, пасека, патока; пра- (прабабуика, правнук, прародина, праязык), впоследствии перешедших в корень. «Приставка су- - это архаичная часть слова, перешедшая во многих словах в корень. Без неё сегодня в русском языке обойтись нельзя, потому что некоторые слова без неё не имеют место быть: супруги - пруги, суржик - ржик».

В персидском дари несколькими значениями обладает приставка /foru-/, например: /foruburdan/(проглотить), /forudāmadan/ (снижаться, приземлиться); иногда употребляется для усиления значения глагола: /bārān foruistād/ (дождь перестал).

Несколько значений имеет и префикс /bar-/: /bardamidan/ (отекать, всходить); barangixtan/ (возбуждать), bargas tan/(возвращаться), /barāvardan/ (выносить).

Префикс /bar-/ является сокращенным вариантом среднеперсидского префикса /aba-/, /avar-/. В языке парсии дари префикс /av-/ был заменен префиксом /bar-/. В произведениях авторов прошлого, а иногда и в настоящее время встречается форма /var-/: varuftādan/, varf ekastan/ (упасть; обанкротиться).

Префикс /bar-/ вносит изменение в семантику некоторых глаголов, например: /zadan/(бить) - harzadan/ (засучить), kes idan/(тащить) barkef idan/(взвешивать), xordan/ (кушать) - barxurdan/ (сталкиваться), 
/barguzār/ (проведение), /barandāz/(расход, трата), /bargiriftan/(получил). Иногда придает глаголу противоположное значение: чидан (собирать) - /barčidan (собрать, подобрать).

В русском языке многозначность отмечена у приставки при-:

- значение прибблиения (приехать, прибыть, примчаться);

- значение близости местоположения, рядом: приикольный, Приднепровье, пригород;

- значение присоединения: привинтить, прибить, прищить, привязать, приивартоваться;

- значение неполноты действия или действия на ограниченный срок: прилечь, приоткрыть, приглуиить звук, притихнуть, принарядиться, nрuсnустить;

- значение доведение действия до конца, до желательной цели: придумать, прищуриться, пристрелить, приучить;

- значение действия, сопутствующего другому действию: пританцовывать, прихлопывать, присвистывать.

Исследование префиксальных глаголов затрагивает различные уровни языка и предполагает разные аспекты лингвистического анализа. Изучению префиксальной семантики и роли глагольных приставок в формировании семантики слова издавна уделялось внимание исследователей по лексической семантике, словообразованию, синтаксису, аспектологии.

Несмотря на долгую историю изучения глагольных приставок сегодня проблема значения приставок является особенно актуальной. Русскими лингвистами признается тот факт, что «выбор приставки и набор значений соответствующего приставочного глагола обусловлен семантикой глагольной основы, наличием или отсутствием у нее определенных семантических признаков» (Кронгауз 1998. 112). 
Приставочные глаголы движения можно разделить на две группы: с приставками пространственных значений и с приставками количественновременных значений.

Глаголы с приставками пространственных значений обозначают направление движения, например: выйти / выходить из комнаты, войти /входить в комнату, а глаголы с приставками количественно-временных значений показывают момент начала движения (пойти в кино); указание на ограниченность движения во времени (походить на тренировку); указание на однократность движения (сходить на почmy); движение с точки зрения охвата объектов перемещения (обойти всю улииу); указание на результат движения (нагуляться за день).

В персидском дари значение «движение вниз» передается приставкой /foru-/ (от forud- (низ, вниз): /foruraftan/, forus udan/ (падать в глубину), foruāmadan/(снижаться), foruāmadan/(спускаться вниз), foruāvardan/ (спускать). Такое же значение имеет и префикс /far-/: cp.: /farāmadan/ foruāmadan/(спускаться вниз), farāvardan-forāvardan/ (снижаться, спускать вниз)».

Значение «движение вверх» в персидском дари может быть передано приставкой /bar-/: /barxāctan/ (подняться), barafkandan/ (бросать вверх), /barnahādan/ (поднять вверx); /bardā $\int \tan /$, har $\int$ udan/ (поднимать(ся).

Приставка /bar-/ также может иметь значение «движение наружу»: /barāmadan/ (выйти), xun barāmadan/ (выходить, вытекать (о крови).

Значение «движение внутрь» передается префиксом /andar-/ landarf enāxtan/. Иногда употребляется в значении «вводить во внутрь» landarkas idan/. В пехлеви употреблась форма /andarag/, в авестийском lantare/, в персидском дари - «/anda/, которая встречается в литературе периода Саманидов (Хаджари 1998. 77). 
Среди русских приставочных глаголов движения наиболее употребительными являются глаголы с приставками пространственного значения. В русском языке насчитывается 21 приставка с пространственным значением. Приставки с общепонятийным компонентом «пространственная направленность» (за-, в3-, на-, над-, при-, по-, пред-, под-, присоединяясь к именной основе, способны выражать пространственные значения, например: задворки, взморье, нагорье, надстройка, приморье, побережье, предгорье, подлесок и т.д. (Иванова Н.С. 1999. 5)

При обозначении движения (действия) с учётом исходного и конечного пунктов русские приставки вносят в глагольные основы различные значения: а) «движение вверх» (над-, под- в3-, (надстроить, надклеить, nодкинуть, взлететь); «движение вниз» (с- (сбежать, сойти, сползти, слезть по лестнице); «движение внутрь» (в- (войти, въехать); «движение наружу» (вы(выйти, выехать); «приближение» (с-, до-, при-, под- (съехать(ся), доехать, приехать, подъехать); «удаление» (за-, от-, у-, раз- (заехать (за что-либо), omъехаmь, уехать, разъехаться); (уехать, уйти); направление движения и др. Значение «направление движения» содержится в самом глаголе, оно выражается и приставками пространственного значения, например: войти в дом. (Засухина. 1992.3).

Описание семантики русских приставок опирается на классификацию пространственных значений (семантических оппозиций). В русских приставках, образующих семантическую оппозицию, ядерными считаются семы «движение вверх - движение вниз», «движение внутрь - движение наружу». Они сохраняются и в тех приставках, в которых преобладает сема «приближение - удаление», которая является основным и наиболее распространённым в приставочных глаголах русского языка. В приставках, образующих семантическую оппозицию «приближение - удаление», ядерными являются семы «приближение» - «удаление», которые сохраняются 
и в тех приставках, которые входят в семантические оппозиции «движение вверх - движение вниз», «движение внутрь - движение наружу». (Азизова М.Э. 2004.38).

В русском языке значение «движение вверх» передается приставками над-, под-, в3- (надстроить, надклеить, подкинуть, взлететь); значение «движение сверху вниз) - приставками с-, под-, низ- (нис-) (съехать с горы, низвергнуть, сбегать, спрьгнуть, спускаться, сойти, сползти, слезть по лестнице).

Значение «перемещение, совершаемое сверху вниз», имеет и русский глагол нисходumb, в котором подчеркивается актуализация антонимических отношений префиксов во3- (со значением «направленность вверх») и низ- (со значением «направленность вниз»).

Как указывает Л.Л. Кутина, глаголы с приставкой низ- возникли как словообразовательный тип со значением «направленность действия сверху вниз»; синонимические отношения установились между префиксом низ- и общеславянским префиксом с- (Кутина 1990. 99).

Значение «движение внутрь» выражается приставками в-, у-: войти, утискать, влететь, вселиться, вбросить, (впустить); а также приставкой во-, в сочетании с которым значение направления движения дублирует предлог в: войти в дом.

Для указания направления движения изнутри («движение наружу») используются приставки вы-, у-, из-: вbinycmumb, уходиmb, выбегать, выбрасывать, выйти, выкопать, вылететь, вынести, выйти, излучать.

Чаще всего приставки соединяются с глаголами следующих семантических групп:

а) движения и перемещения в пространстве (добежать);

б) действия (внести);

в) физиологических действий и процессов (вblcnambcя);

г) приобщения или отчуждения (забрать); 
Необходимо отметить и то, что приставки с пространственным значением также обозначают:

а) части человеческого тела (надбровье, надгортанник, надкостница,);

б) пространство земной поверхности (побережье, поречье, Поволэье, Подонье, нагорье);

в) конкретные предметы, имеющие объём; положение на поверхности предмета: нагрудник, наконечник, наплечник, нарукавник, наручник, науиник.

В ходе анализа также были выявлены префиксы /na-/, /ne-/, /nā-/ со значением отрицания, указывающие на отсутствие качества, например, /narafte/, /naxurd/ (неушедший, не есть), /nasuz/ (несгораемый), /nāamn (небезопасный), /naxurdan/(не принимать пищу), /mehmāne nāxānde/ (незваный 20cmb).

«Некоторые глагольные префиксы (na-, me-, bi-), присоединяясь к глагольным основам, образуют грамматические формы, выражающие новые оттенки значений (отрицание, время, эмоциональную окрашенность и т.п.). Префикс /na-/, присоединяясь к глаголу, образует отрицательную форму и выражает значение невозможности или нежелательности выполнения действия, например: /naru (не ходи), /nagirad/ (чтобы не брал), /nadid/(не увидел), /namejunbad (не двигается),/mulāghāt najuyad (не ищите встречи).

Префикс / ne-/ пишется в начале слова перед префиксом / me-/, в других случаях - префикс /na-/, ср.: /nemiravam/ (не поеду) - naravam/ (если мне не идти) (Хаджари 1998. 228-229).

Значение отрицания также несет префикс /be-/: /bighuvvat/ (бессильный, слабый), bixuS/ (без сознания), bigumān/ (без сомнения), bikār (безработный), hiaghl/ (тупой, без ума), ljāye bixata// (безопасное место), /ādam-e bi taraf/ (нейтральный человек), /bigharāri/(беспокойство), bieyb/ (без недостатков, без дефектов). В среднеперсидском языке вместо префикса /be-/ использовалась форма /abi-/, в пехлеви - /ui/, в авесте и санскрите - /vay/. 
Префикс /nā-/ в отличие от префиксов /be-, bā-, bi -, na-/ в основном употребляется с именами прилагательными (Хаджари 1998. 230-231): /bimāri nāumid/ (безнадежный больной); /vojud-e nāpāk/ (нечистая совесть); /jāhāye $n \bar{a} \int$ enās/ (незнакомые места); bačaye $n \bar{a} \int u d /$ (негодный ребенок), /aspe $n \bar{a} \bar{a} z m u d /$ (неезженная лошадь). С его помощью образуются семантические пары с отрицательным значением: /binā/ (зрячий) - /nābinā/ (незрячий, слепой), /ma'lum/ (явный, известный) - /nāma'lum/ (неявный, незвестный).

В русском языке для образования слов с противоположным значением используется префикс не- (быль - небылица), (сильный - несильный), (трудный - нетрудный).

Префикс не- образует существительные, называющие предмет или лицо, не совершающее, не способное совершить действие или подвергнуться действию: незнайка, непроливайка; отсутствие действия: неполадка, нехватка (хватать иметься в достаточном количестве), неувязка; непоседа (от посидеть), недотрога (от дотронуться), неумоя (разг.) (от умыться, умоются), неулыба (от улыбаться) Данные типы слов встречаются в разговорной речи, окказионализмах: несработка (от сработаться).

Префикс не- можно встретить в некоторых отглагольных существительных: неимение, непротивление, неверие; неразбериха (разг.); неумеха (прост.); невидаль и невидальщина.

«Во многих случаях можно легко найти однокоренное слово без приставки не-, относящееся к другому грамматическому классу, но простое отсечение приставки создает несуществующее в языке слово: негаданный - гадать, гадание; нелепьй-лепота; невтерпёж-терпеть, терпение».

Некоторые слова с приставкой не- в русском языке потеряли исходные формы, например: нельзя, немножко, невмоготу, непролазный, неожиданный и др. 
Как отмечает В.В. Баранов, «русский язык не обладает собственным префиксом, выражающим процесс лишения предмета его признака или качества» (Баранов 1996. 18).

По этой причине в русскую словообразовательную систему вошли заимствованные приставки, указывающие на отсутствие у предмета определенного качества, признака или свойства (а-, дис-, лже-, псевдо-, анти-, контр- и др).

Префикс а- называет явление, характеризующееся отсутствием того, что названо мотивирующим словом (ритм - аритмия, тон - атония), употребляется в медицинских терминах.

Приставка дис- отличается от приставки не- (отрицающей качество или признак предмета, ср.: негармония - дисгармония, непропорчия диспропориия) тем, что указывает на отсутствие у предмета определенных качеств или свойств путем указания на несоответствие, расхождение с теми или иными качествами и свойствами, например, в слове гармония помимо отсутствия качества гармонии, приставка дис- также указывает на несходство, расхождение с данным качеством.

Заимствование приставки дис- способствовало обогащению словарной системы русской языка единицей, обладающей семантикой, не присущей русской приставке, хотя и не явилась словообразовательным средством. В современном русском языке слова с приставкой дис- используются лишь в терминологии (диспропориия, дисбаланс, диссимметрия).

В словообразовании персидского дари также используются префиксы /ba-/, /be-/, образующие новые формы глагола с оттенком необходимости: bene inad/ (пусть сядет), /bemānad/ (пусть останется) $u$ /berizand/ (пусть выльют), /nehādan/ (положить) - banahādan/ (пусть положит), bebāyad dānest/ (необходимо знать). 
Модальное слово /bāyad/ (должен, следует, необходимо) употребляется перед глаголом. Данное явление наблюдается и в русском языке, ср.: /bāyad barxāst - необходимо подняться, /

Префикс /ba-/ образует причастие и прилагательные от абстрактных существительных (Хаджари 1998. 86-89): bazudi/ (вскоре), baāhistagi/ (медленно), baqāyat/ (весьма, очень), /batadrij/=/tadrijan/ (постепенно).

Причастия, образованные с помощью префикса /be-/, не следует путать с повелительной формой глагола: Һesāz// (от /sāzgār/ (подходящий) - besāz/ (строй), bezan/ (тот, кто хорошо бьет).

Префикс /bā-/ образует от абстрактных существительных имена прилагательные и наречия: например, /bāsalāmat/ (здоровый), /bālazzat/ (вкусный), /bāxatar/ (опасно), /bātalā / (старательно), /bāustoxān/ (костлявый), bāma'zarat/ (вредный) (Бахар 1994. 91-92).

Префиксы /bā-/ и /ba-/ могут взаимо заменять друг друга, например, bačaye bāadab;baadab/ (воспитанный мальчик), /ādame bāandif e;baandif e/ (рассудительный человек).

Префикс /bā-/ образует качественные прилагательные, обозначающие признак предмета: ffekre bāma'ni/ (разумная мысль), /ānae bābarakat/ (плодородное семя).

Префикс /bār-/ имеет значение обладания предметом или лицом какимлибо признаком или качеством, например: /suxanhaye bardoruq/ (ложные слова), /taS viqe barziyād/ (излишняя пропаганда), /aqle barkamāl/ (развитый ум).

Префикс $/ \bar{a} \bar{z}-/$ является продуктивным аффиксом, указывает на повторное выполнение действия (Фаршидвард 2009. 94-95). В пехлеви употреблась форма /āpāč/, в авестийском - /āpāk/, в среднеперсидском - /ābāz/ (сначала, заново, опять).

Префикс $\boldsymbol{b} \bar{a} z-/$ реализует значение «периодически повторяющееся действие, указанное в корне», например: /bāzguftan/ (повторить), /bāzāvardan/ 
(вернуть), bāzgereftan (забрать), /bāzdidkardan (встречаться), /bāzxāstan/(отозвать), bāzpas/(обратно), bāzāmadan (возвращаться/ вернуться), $b \bar{a} z \int$ enāxtan/ (сознавать). В русском языке данное значение передается с помощью приставок на-, пере- (наводить, навозить, начесать; пересказать).

Как отмечает М. Бахар в книге /sabkf enāsi/, префикс /bāz-/ в древности имел несколько значений: «назад», «наоборот», «повторное действие». Как и некоторые другие префиксы, он изменяет значение глагола: ср.: /xāstan (хотеть, просить) - /bāzxāst/ (отзыв) (Бахар 1994. 341-343].

Префикс /bāz-/ усиливает значение глагола, который принимает новый смысловой оттенок, ср.: /ga $\tan /$ (ходить) - /bāzgaS tan/(вернуться), /istādanbāzistādan/(останавливаться); $\quad \operatorname{bārad}$ (имеет, держит) bāzbārad;kardan/(делать, совершать действие) - /bāzkardan(az $\left.\int \mathrm{ir}\right) /$ (отлучить (от груди), /āmadan/ (идти) - /bāzāmadan/(возвращаться).

Префикс /bāz-/, присоединяясь к глагольной основе, образует новый глагол со значением «повторного действия», например, /āmadan/ (приходить, прийти) - $\quad$ bāzāmadan/(вернуться), /dā $\int \tan /\left(\right.$ владеть, иметь) - bāzdā $\int \tan /$ (препятствовать, удерживать), /istādan/(стоять) - /bāzistādan/ (остановиться).

Иногда префикс /bāz-/ используется для усиления значения (бозпасоварандан). Также префикс /bāz-/ может выступать в качестве синонима префикса /bar-/, например: /bāzgas tan - bargas tan/ (вернуться, возвращаться).

Префикс /par- /, в древнеперсидском использовалась форма /pari/, в авестийском -lpiri/ (окружение): parākanda $\int u d a n$ (рассеиваться, рассыпаться).

Префикс /do $\int /$, в пехлеви - /du $\int /$, в авесте - /du $\int-$, duzh-/, в санскрите /dur-, dus-, duS/, имеет следующие значения: /duru $\int \mathrm{ti} /$ (жесткость), /durust/ (правильно, хорошо). Например, слово $/ d u \int \operatorname{man} /\left(d u \int\right.$ (плохо) + man (от 
«manif » (природа, характер) употребляется в значении «плохая натура», «плохой характер».

В современном персидском языке вместо слова $/ d u \int x \bar{a} r /$ употребляется форма $/ d u \int v \bar{a} r /$ (трудный), состоящий из /duS/(грубый, некрасивый) и vār/(трудный). В словаре Мунна встречается форма /duzhvār $/$.

\section{Заключение}

Таким образом, проведенный анализ позволяет сделать вывод, что с древних времен по настоящее время одним из способов словообразования является использование аффиксов. В разные исторические периоды отмечается лишь разница в степени употребления аффиксов и изменение их значений.

Как показывает анализ персидских дари и русских глаголов, префиксальный способ - является продуктивным при образовании как существительных и прилагательных, так и при образовании глаголов.В обоих рассматриваемых языках приставки выполняют две функции: грамматическую и лексическую. Как нам кажется, изучение семантики приставок необходимо проводить в тесной взаимосвязи между глагольными основами и приставками. Проведенный анализ позволяет предположить, что описание приставочных глаголов позволит найти в будущем оптимальный способ семантизации как персидских дари, так и русских приставочных глаголов для персоязычных учащихся.

\section{Литература}

1- Азизова М.Э. (2004). Способы передачи русских глаголов с приставкой за- на таджсикский язык. дис. канд.филол.наук. Душанбе. ТГПУ

2- Баранов, В.В. (1996). История словообразования префиксальньтх существительных в русском языке ХИІІІ-ХХ вв. (на материале производных с приставками анти-, контр-, противо-, де-/дез-, дис-, а-, лже-, псевдо-, квази) дис. канд.филол.наук. Москва. Институт русского языка им. В.В. Виноградова PAH. 
3- Бахар, Мохаммадтаги (1994). Сабкиенаси [Стилистика], том 1, Тегеран. Издво «Амир Кабир». 467 с.

4- Волохина Г.А., Попова З.Д. (1994). Русские приставочные глаколы и их значения: Учебное пособие для практ. Занятий. Воронеж: 1. Изд-во «ВГУ».

5- Джурджани Сейид Исмаил. (1987). Захираи Хорезмиахи (Сокровищница Хорезмшаха). Тегеран. Изд-во «Анджоман Асари милли».

6- Засухина Т.П. (1992). Пространственная семантика предлогов, приставок и падежей в современном русском языке. дис. канд.филол.наук. Екатеринбург. Уральский государственный университет им. А.М. Горького.

7- Иванова Н.С. (1999). Семантика русских глагольных приставок е префиксальном словообразовании: На материале ЛСГ глаголов трудовой деятельности. Дис. ... канд. филол. наук. Москва. Государственный институт русского языка им. А.С. Пушкина.

8- Кронгауз М.А. (1998). Приставки и глаголы в русском языке: семантическая грамматика. Москва. Изд-во «Школа Языки русской культуры».

9- Кутина Л.Л. (1990). К вопросу о неославянизмах с приставкой низ- в русском языке XVIII века // Развитие словарного состава русского языка ХИІІ века. : вопросы словообразования. Ленинград. «Наука». - С. 99-113.

10- Мешкато-Дини, Мехди (2009). дастур-э забан-е-фарси; важиган ва пейвандхае сахти [Персидская грамматика; лексические категории и слияния], 4-е издание, Тегеран. Изд-во «Организация по изучению и составлению гуманитарных книг вузов - САMТ». $247 \mathrm{c}$.

11- Морковкин В.В. (1981). Лексическая многозначность и некоторые вопросы лексикографической интерпретации // Русский язык: Проблемы художественной речи, Лексикология и лексикография. Москва, Изд-во «Наука», С.45-67.

12- Нател Ханлари Парвиз (1975). mapux-е забан-е фарси [История персидского языка]. Тегеран. Изд-во «Боняд-е фарханг-е Иран».

13- Нисори Ходжа Хасан (1998). Четыре чветника /Нисари Ходжа Хасан [Чахор гулзор]. -Душанбе. Изд-во «Шарќи Озод». -119 c.

14- Падучева Е.В. (2002). Дейктические компоненты в семантике глаголов движения // Логический анализ языка. Семантика начала и конца. Москва, Изд-во «Индрик», - С. 121-136

15- Почтарева О.В. (2001). Производньле со значением аннулирования 6 современном русском языке, автореферат дис. ганд фипол. наук Тюмень. ТюмГУ.

16- Спагис, А.А. (1969). Парные и непарные глаголы в русском языке. Москва. Изд-во «Просвещение». 
17- Фаршидвард Хосро (2009). Дастури мухтасар эмруз бар паяи забаниеноси джадид [Современная краткая грамматика на основе новой лингвистики], Тегеран. Изд-во «Сохан». $414 \mathrm{c}$.

18- Хаджари Зийеддин (1998). Фарханг-э вандхайе забан-е-фарси [Словарь приставки и суффиксы в персидском языке], Тегеран. Изд-во «Авайе Нур». $326 \mathrm{c}$.

19- Шерба Л.В. (1974). О частях речи // Языковая система и речевая деятельность. Ленинград. Изд-во «Наука» - С.79-121.

\section{Bibliography}

1- Azizova M.E. (2004). Sposoby peredachi russkih glagolov s pristavkoy za- na tadzhikskiy yazyk. dis. kand.filol.nauk. Dushanbe. TGPU .

2- Baranov, V.V. (1996). Istoriya slovoobrazovaniya prefiksal'my suschestvitel'nyh v russkom yazyke XVIII-XX vv. (na materiale proizvodnyh s pristawkami anti-, kontr-, protivo-, de-/dez-, dis-, a-, lzhe-, psevdo-, kvazi-). dis. kand.filol.nauk. Moskva. Institut russkogo yazyka im. V.V. Vinogradova RAN.

3- Bahar, Mohammadtagi (1994). Sabkshenasi [Stilistika], tom 1, Tegeran. Izd-vo "Amir Kabir". 467 s.

4- Volohina G.A., Popova Z.D. (1994). Russkie pristavochnye glagoly i ih znacheniya: Uchebnoe posobie dlya prakt. Zanyatiy. Voronezh:1. Izd-vo "VGU".

5- Dzhurdzhani Seyid Ismail. (1987). Zahirai Horezmshahi (Sokrovischnica Horezmshaha). Tegeran. Izd-vo "Andzhoman Asari milli".

6- Zasuhina T.P. (1992). Prostranstvennaya semantika predlogov, pristavok $i$ padezhey $v$ sovremennom russkom yazyke. dis. kand.filol.nauk. Ekaterinburg. Ural'skiy gosudarstvennyy universitet im. A.M. Gor'kogo.

7- Ivanova N.S. (1999). Semantika russkih glagol'nyh pristavok v prefiksal'nom slovoobrazovanii: Na materiale LSG glagolov trudovoy deyatel'nosti. Dis. ... kand. filol. nauk. Moskva. Gosudarstvennyy institut russkogo yazyka im. A.S. Pushkina.

8- Krongauz M.A. (1998). Pristavki i glagoly v russkom yazyke: semanticheskaya grammatika. Moskva. Izd-vo "Shkola Yazyki russkoy kul'tury".

9- Kutina L.L. (1990). K voprosu o neoslavyanizmah s pristavkoy niz- v russkom yazyke XVIII veka // Razvitie slovarnogo sostava russkogo yazyka XVIII veka. : voprosy slovoobrazovaniya. Leningrad. Izd-vo "Nauka". - S. 99-113.

10- Meshkato-Dini, Mehdi (2009). dastur-e zaban-e-farsi; vazhigan va peyvandhae sahti [Persidskaya grammatika; leksicheskie kategorii i sliyaniya], 4-e izdanie, Tegeran. Izd-vo "Organizaciya po izucheniyu i sostavleniyu gumanitarnyh knig vuzov - SAMT". $247 \mathrm{c}$. 
11- Morkovkin V.V. (1981). Leksicheskaya mnogoznachnost' i nekotorye voprosy leksikograficheskoy interpretacii // Russkiy yazyk: Problemy hudozhestvennoy rechi, Leksikologiya i leksikografiya. - Moskva, - S.45-67.

12- Natel'hanlari Parviz (1975). tarih-i zaban-e farsi, tom 1; Iran, Tegeran.

13- Nisari Hodzha Hasan (1930). Chetyre cvetnika / Hodzha Hasan Nisari; per. Grishin M. Bektasha V. - Tashkent. - 20 c. (na tadzh. yaz.).

14- Paducheva E.V. (2002). Deykticheskie komponenty v semantike glagolov dvizheniya // Logicheskiy analiz yazyka. Semantika nachala i konca. Moskva, - S.

15- Pochtareva O.V. (2001). Proizvodnye so znacheniem annulirovaniya $v$ sovremenmom russkom yazyke, avtoreferat diss. kand. filol. nauk.

16- Spagis A.A. Parnye i neparnye glagoly v russkom yazyke. M.: "Prosveschenie", 1968.

17- Farshidvard Hosro (2009). Dasturi muhtasar emruz bar payai zabanshinosi chadid, 'sohan Izdatel'stvo", Tegeran $414 \mathrm{~s}$.

18- Hadzhari Ziyeddin (1998). Farhang-e vandhaye zaban-e-farsi, entesharat "Avaye Nur", Tegeran. $326 \mathrm{~s}$.

19- Scherba L.V. (1974). O chastyah rechi // Yazykovaya sistema i rechevaya deyatel'nost'. L., - S.79-121.

HOW TO CITE THIS ARTICLE

Ахмади, 3., Мухаммадбегии Косвои, М., \& Хаитова, Ш.

(2019). Comparative Analysis of Derivational Prefixes of Dari

Persian and Their Russian Equivalent. Issledovatel'skiy

Zhurnal Russkogo Yazyka I Literatury, 7(2), 187-205.

DOI: 10.29252 /iarll.13.2.187

URL: http://www.journaliarll.ir/index.php/iarll/article/view/87

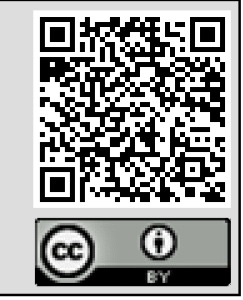




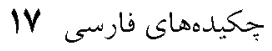

مقايسه تحليلى بيشوندهاى اشتقاقى در زبانهاى فارسى درى و روسى

$$
\begin{aligned}
& \text { زهرا الحمدى' } \\
& \text { دكتراي زبانشناسى دانشگاه ملى تاجيكستان، } \\
& \text { دوشنبه تاجيكستان }
\end{aligned}
$$

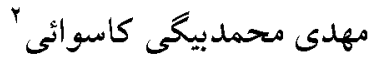

$$
\begin{aligned}
& \text { دكتراي زبانشناسى دانشخاه ملى تاجيكستان، } \\
& \text { دوشنبه تاجيكستان } \\
& \text { شيرين حاليتوراr } \\
& \text { دانشيار، دانشخاه ملى تاجيكستان، } \\
& \text { دوشنبه تاجيكستان. } \\
& \text { (تاريخ دريافت: زانويه 19.ب: تاريخ بذيرش: مه 19.r) }
\end{aligned}
$$

در اين معاله، نويسندكان به تجزيه و تحليل معايسسهاى يـشيوندهاى اثـتقاقى در زبـانهـاى

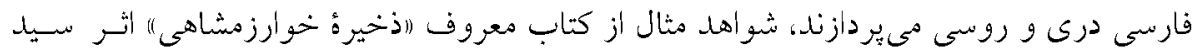

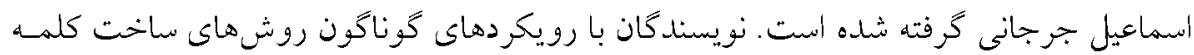

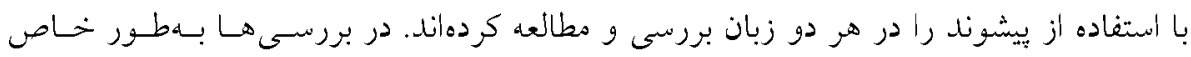

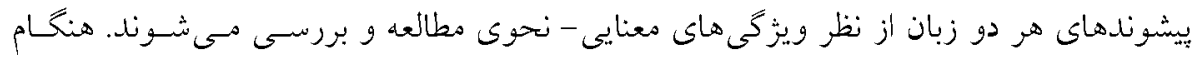

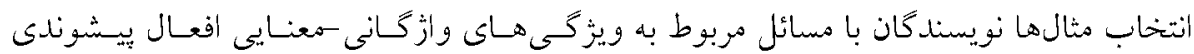

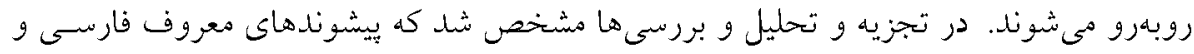

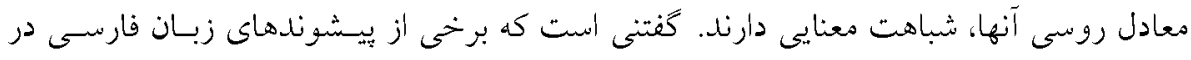

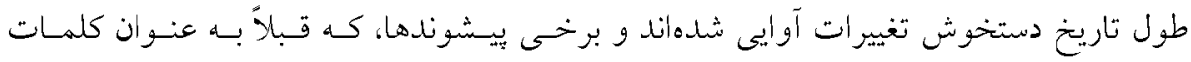
جداكانه استفاده مى شدند در طول زمان، به يكى تكواز اشتقاقى تبديل شدهاند.

$$
\text { وازًٔان كليدى: تكىواز، وند، ييشونا، معنى، زايا، غيرزايا، زبان فارسى، زبان روسى. }
$$

1. E-mail: ahmadikazahra@yahoo.com

2. Email: mahdimb@yahoo.com

3.E-mail: haitova@inbox.ru 